\title{
Diet in The Intensive Phase of Pulmonary Tuberculosis Patients
}

\author{
Desy Indra Yani, Hilman Saiful Islam, Citra Windani Mambang Sari \\ Faculty of Nursing, Universitas Padjadjaran \\ Email: hilman.saiful.islam@gmail.com
}

\begin{abstract}
Diet is an important component in the treatment of tuberculosis (TB). The diet is a daily nutrition fulfillment. The nutrition means macronutrient and micronutrient. The lack of macronutrient and micronutrient intake in tuberculosis patients could be a high risk for patients. Lack of nutrition can be addressed from the low level of BMI in TB patients. Both malnutrition and TB influence each other, malnutrition increases the risk for TB and TB could cause malnutrition. The aim of this study was to describe the diet of tuberculosis patients in the intensive phase. The study was conducted in two primary health cares in Bandung city. This study was a descriptive-quantitative research that used consecutive sampling method. The samples were 36 TB patients in the intensive phase. The data was gathered using 3 days food record and analyzed using the descriptive statistics method. The study's result indicated that $86.1 \%$ of TB patients consumed calories less than their need, $80.6 \%$ of TB patients consumed carbohydrates meet the needs, $83.3 \%$ of TB patients consumed protein less than necessity, $55.6 \%$ of TB patients consumed fat meet their needs, and $100 \%$ of TB patients consumed vitamin D less their need. The study results showed that the diet of TB patients was less than their need. This study concludes that in general, the diet in TB patients is still less than their need, especially protein and vitamin D. While carbohydrates and fat met the patients'need. Based on this result, the researcher recommends that the primary health care in Bandung city should provide counseling services about various food types that need to be consumed by TB patients to fulfill calory, protein, and vitamin D daily needs.
\end{abstract}

Keywords: Diet, Intensive phase, pulmonary tuberculosis. 
Desy Indra Yani : Diet in The Intensive Phase of Pulmonary Tuberculosis Patients

\section{Introduction}

Tuberculosis is a global health problem because it affects millions of people. This disease is also the number one disease cause of death in the world. The number of TB patients worldwide in 2014 was estimated at 9.6 million people with a proportion of 5.4 million men, 3.2 million women, 1 million children, and about 1.5 million people died from TB. Currently, Indonesia is the second rank of TB sufferers in the world. Indonesia has $10 \%$ of total TB patients worldwide with a prevalence of around 1.6 million people and an incidence between 700 thousand and 1.4 million new TB patients per year (WHO, 2015). West Java is ranked first in Indonesia with 65,275 total TB sufferers and 31,231 new TB patients (Ministry of Health RI, 2015). In regard to TB treatments, WHO as an international health organization has guidelines in the treatment and care of TB (WHO, 2010).

In WHO treatment and care guidelines mentioned that the diet or the fulfillment of nutrition is an important factor in supporting the recovery of TB patients. Diet is important because nutrition can be a cause as well as a result of TB disease. Lack of nutrients is very often associated with diseases and infections such as gastrointestinal disease and mal-absorption, pneumonia, TB and HIV (WHO, 1999). The link between nutritional deficiencies and TB has been known for a long time, nutritional deficiencies can decrease immunity, increasing the risk of latent TB becoming active TB (Cegielski \& McMurray, 2004) and TB disease exacerbating nutritional deficiencies because TB patients experience catabolism and weight loss conditions (Zachariah et al., 2002; Dodor, 2008). There is limited evidence that malnutrition affects people with latent TB, whereas much evidence suggests that malnutrition is common in active tuberculosis patients (Schaible, 2007).

Nutrition, immunity, and infection have been known as a complex interactions and dynamic relationships. Infection is both a consequence and a precipitating factor in protein-energy malnutrition in a population. It affects the decline of productivity, increased socioeconomic problems, disrupts political stability, and inhibits the productive capacity of society (Schaible, 2007). The individuals that most susceptible to TB bacteria but have sufficient immune responses to eliminate TB bacteria in their body can avoid further progression of TB disease, only about $10 \%$ of people who have latent TB infection will develop active TB infection throughout their lives (Mack, 2009)

Weight loss in tuberculosis patients may be caused by factors such as loss of nutrition from vomiting and diarrhea, nausea and abdominal pain, decreased appetite resulting in reduced dietary intake (Metcalfe, 2005; Podewils et al., 2011) and metabolic changes caused by TB disease (WHO, 2013). TB patients decreased appetite caused by increased hormones that inhibit appetite, including peptide plasma YY, ghrelin and resistin. But the appetite inhibiting hormone will decrease when the patient in the treatment period. (Chang et al., 2013)

Decreased appetite in TB patients can prove by decreased of BMT, low levels of subcutaneous fat, and weak hands of TB patients (PrayGod, 2011). Several crosssectional studies have also shown that low body mass index (IMT) is associated with $\mathrm{TB}$, which suggests that the higher the BMI the incidence of TB incidence in a person tends to decrease (Lonnroth, 2010). Another study in Malawi explained that severe malnutrition is associated with death and the risk will increase if the patient has a low BMI (Zachariah et al., 2002). A study conducted by Munro in Norway in 1945, McKeown's analysis of TB deaths in England from 1770 to 1900 described that the most responsible for reducing TB deaths is a good diet (WHO, 2013).

The low intake of macronutrients may decrease the nutritional status of TB patients resulting in a decrease in body mass index below the normal limit of $18.5 \mathrm{~kg} / \mathrm{m}$. Then, if this matter not immediately overcome by increasing the body weight it can deteriorate the prognosis as well as recurrence (Khan et al. 2006; Krapp et al., 2008). Lack of protein calorie intake in TB patients may also increase the risk of death (Hanrahan et al., 2010). Several epidemiological studies have shown a correlation between deaths caused by $\mathrm{TB}$ and malnutrition with biochemical 
Desy Indra Yani : Diet in The Intensive Phase of Pulmonary Tuberculosis Patients

parameters, such as the high risk of death of TB patients with low serum albumin (Waitt et al., 2011). TB patients with BMI below 18.5 $\mathrm{kg} / \mathrm{m}$ are at risk of death, especially those with TB who had TB treatment for less than 8 weeks or in an intensive treatment phase (Lai et al., 2017). The study of Birlie et al. in 2015 in Ethiopia stated that a total of TB deaths were 60 cases from 810 TB patients, 34 deaths occurred in the intensive phase.

In malnutrition, decreasing the micronutrient intake is also associated with impaired immune responses. Micronutrients include minerals, vitamins, and other organic substances. Several studies have attempted to investigate micronutrient deficiencies with $\mathrm{TB}$, but often researchers find it difficult to explain that deficiency as a cause or as a result of TB (Nnoaham \& Clarke, 2008). The micronutrients that decreased in the body during the intensive phase of TB treatment include vitamin $\mathrm{A}, \mathrm{E}, \mathrm{D}$, iron, zinc, and selenium (WHO, 2013)

The level of Vitamin D in each individual fluctuate every time, and most are very low when winter in North American and European countries due to decreased exposure to sunlight. This observation found that there is a relationship between vitamin D and TB intake deficits, leading to the hypothesis that vitamin $\mathrm{D}$ deficits contribute to the onset of TB disease. The vitamin $\mathrm{D}$ deficit has provided explanations to researchers about TB reactivation in migrants from tropical countries with good sun exposure to northern or northern Europe (Nnoaham \& Clarke, 2008).

Several studies in Indonesia on nutritional intake and nutritional status concluded that carbohydrate deficits occurred in $66.7 \%$ of TB patients in Surakarta City and protein deficits occurred in $57.8 \%$ of $\mathrm{TB}$ patients, and the nutritional status (BMI) of the study subjects were normal (46.7\%) (Wisnugroho, 2014). While a study in Makassar found the average of energy intake of TB patient was $1144.4 \pm 455.0 \mathrm{Kcal}$, nutritional status in the most $\mathrm{TB}$ patients had less nutritional status $(51.3 \%)$ than normal nutrient status $(40.7 \%)$ and fat (8.0\%) (Arsin et al., 2012). Research on vitamin D intake in TB patients in Indonesia has been done in Padang, the study found $\mathrm{TB}$ patients did not meet the daily vitamin D requirement (Fadhila, 2015). Research conducted in Indonesia on nutrition intake in tuberculosis patients mostly using the retrospective method, where less study applied patients record of daily food intake by remembering backward (food record). Food record is a detailed protocol on consumption of food and beverages within a specified time period, usually for 3,5 or 7 days. Ideally, food record replenishment is done when we eat and drink to minimize our dependence on memory and recording of portions, brand names, composition and methods of cooking food. This will change the mindset of the patient when eating by changing their eating habits (Thompson et al., 2008). Traditional food record patterns have low difficulty and the possibility of not being recorded is very minimal (Shattuck, 2005).

The unavailability of nutritionists to serve health services becomes an opportunity and a duty for nurses to fill the role of nutrition counselors. Nurses do not get an adequate education in the field of nutrition, but nurse opportunities in the field of nutrition as educators and researchers open wide (Henning, 2009). To fulfill the role of an educator of course nurses need to know the practice of diet in tuberculosis patient before preparing information about nutrition. Therefore, researchers want to examine the diet in patients with intensive phase TB in the PHC of Garuda and Sukajadi Bandung.

\section{Research Method}

The research design in this research was descriptive research. According to Polit \& Beck in 2010, descriptive research aims to observe, describe and documenting aspects of a situation. In this study researchers observed, described and documented the diet of patients in the intensive phase of pulmonary tuberculosis at the PHC of Garuda and Sukajadi Bandung.

The main concept of this study was diet. Diet according to Beck in 2000, is a food choice commonly eaten by a person or a group. According to Webster-Gandy et al. in 2014 diet is a habit of eating and drinking, so every individual must be dieting. Diet has 
Desy Indra Yani : Diet in The Intensive Phase of Pulmonary Tuberculosis Patients

a value that is assessed using the size of the energy and nutritional content of a special diet. The diet itself consists of macronutrients (carbohydrates, proteins and fats) and micronutrients (vitamins and minerals) (Webster-Gandy et al., 2014).

The population in this study were all patients with the intensive phase of pulmonary TB in Garuda and Sukajadi health centers, Bandung city. Data collection time was 1 month. There were intensive phase TB patients in each PHC, 43 patients from the Garuda PHC, and 9 patients from in Sukajadi. This research used the consecutive sampling technique, the researchers determined the time limit of data retrieval in 1 month. The final samples were $36 \mathrm{~TB}$ patients.

Diet measured using food record. Food record is a record of all foods and beverages intake consumed by the respondent during a predetermined period of time, usually 3,5 or 7 days in the household size (URT) whose calorie count is calculated using Nutrisurvey software with measurements in kilocalories (kcal). Validity test did through content validity with the expert lecturer. The food record instrument measured the type and amount of food consumed by the respondent since the instrument was already open-ended and will get valid data. To ensure that the data obtained from respondents are correct, the researcher had explained to the respondent about the procedure of writing the type and quantity of food in table food record so that the respondent is able to give the correct data. To know the bias of the instrument researchers have done a pilot study by asking 3 respondents to fill the food record table, then researchers have asked about obstacles and difficulties in filling food record, the result of the three respondents said no difficulty in charging.

Data analysis in this study used univariate analysis. The univariate analysis aims to explain or describe the characteristics of each research variable (Notoatmodjo, 2012). Type of food that has been written by the respondent and the amount in the size of the household changed to grams and milliliters. The content of the food was then calculated using the software Nutrisurvey with the results of measuring in kilocalories (kcal). After obtaining the amount of food intake in kilocalories, carbohydrate, fat and protein and vitamin D data were grouped into less, more and more of the needs.

\section{Research Results}

Demographic characteristics in this study include gender, religion, ethnic group, education, occupation, Earnings, distance from home to health care provider and the number of family members. Table 1 . present the frequency distribution table for each

Table 1 Characteristics Demographics of Patients TB ( $=36)$

\begin{tabular}{lcc}
\hline \multicolumn{1}{c}{ Characteristics } & Frequency & Percentage \\
\hline Gender & 13 & 36.1 \\
Male & 23 & 63.9 \\
Female & & \\
Religion & 33 & 91.7 \\
Muslim & 3 & 8.3 \\
Christian & & \\
Ethnic Group & 31 & 86.1 \\
Sundanese & 4 & 11.1 \\
Javanese & 1 & 2.8 \\
Chinese & & \\
Education & 1 & 2.8 \\
Uneducated & 11 & 30.6 \\
Elementary & 10 & 27.8 \\
Junior High School & &
\end{tabular}


Desy Indra Yani : Diet in The Intensive Phase of Pulmonary Tuberculosis Patients

\begin{tabular}{lcc}
\hline Senior High School & 12 & 33.3 \\
College/University & 2 & 5.6 \\
Occupation & 11 & 30.6 \\
Private Employee & 5 & 13.9 \\
Entrepreneur & 7 & 19.4 \\
Housewife & 6 & 16.7 \\
Student & 7 & 19.4 \\
Unemployment & & \\
Marital status & 12 & 33.3 \\
Unmarried & 21 & 58.3 \\
Married & 2 & 5.6 \\
Divorce & 1 & 2.8 \\
Divorce (her spouse was death) & & \\
Earnings & 24 & 66.7 \\
Below regional minimum wage & 12 & 33.3 \\
Above regional minimum wage & & \\
Distance from home to health care & & \\
provider & 28 & 77.8 \\
$0-5 \mathrm{Km}$ & 8 & 22.2 \\
$6-10$ Km & 0 & 0 \\
$<10$ Km & & \\
\hline
\end{tabular}

Tabel 2 Characteristic of Respondents $(\mathrm{N}=36)$

\begin{tabular}{llll}
\hline \multicolumn{1}{c}{ Characteristic } & Frequency & Percentage \\
\hline Smoking & 1 & 2.8 \\
Smoker & 20 & 55.6 \\
Non-smoker & 15 & 41.7 \\
Ex-smoker & & \\
Symptom & 28 & 77.8 \\
Nausea & 4 & 11.1 \\
Vomiting & & \\
BTA Status & 17 & 47.2 \\
Negative & 19 & 52.8 \\
Positive & & \\
Comorbidities & 2 & 5.6 \\
Diabetes & 34 & 94.4 \\
No. comorbidities & & \\
Relative with TB & 7 & 19.4 \\
Yes & 29 & 80.6 \\
No & & \\
Symptoms & 25 & 69.4 \\
1-4 weeks & 7 & 19.4 \\
5-8 weeks & & \\
\hline
\end{tabular}


Desy Indra Yani : Diet in The Intensive Phase of Pulmonary Tuberculosis Patients

\begin{tabular}{lcccc}
\hline$<8$ weeks & \multicolumn{3}{c}{ 4 } & \\
\hline \multicolumn{2}{l}{ Tabel 3 The Need for IMT and Calory of Patient TB (N=36) } \\
\hline \multicolumn{1}{c}{ Characteristic } & Minimum & Maximum & Mean & Std. Deviation \\
\hline Weight & 31.5 & 60.0 & 47.39 & 7.90 \\
TB & 138.0 & 170.0 & 157.56 & 8.70 \\
IMT & 13.7 & 28.8 & 19.19 & 3.57 \\
Weight & 47.0 & 69.0 & 57.61 & 6.35 \\
Calory needed & 1504.0 & 2960.0 & 2101.97 & 413.01 \\
\hline
\end{tabular}

Tabel 4 Consumption of Nutrients Per Day of The Patient TB (N=36)

\begin{tabular}{|c|c|c|c|c|}
\hline Variable & Minimum & Maximum & Mean & Std. Deviation \\
\hline \multicolumn{5}{|l|}{ Calory } \\
\hline Day 1 & 742.5 & $3,509.0$ & $1,681.1$ & 540.43 \\
\hline Day 2 & 665.5 & $3,033.7$ & $1,508.1$ & 440.03 \\
\hline Day 3 & 607.4 & $2,591.7$ & $1,557.4$ & 438.94 \\
\hline Average & 671.8 & $3,044.8$ & $1,582.3$ & 420.69 \\
\hline \multicolumn{5}{|l|}{ Carbohydrate } \\
\hline Day 1 & 113.4 & 539.1 & 239.22 & 84.82 \\
\hline Day 2 & 79.9 & 381.1 & 222.65 & 80.76 \\
\hline Day 3 & 61.8 & 462.4 & 225.32 & 82.71 \\
\hline Average & 85.0 & 407.0 & 228.96 & 68.60 \\
\hline \multicolumn{5}{|l|}{ Protein } \\
\hline Day 1 & 21.8 & 108.2 & 48.73 & 18.92 \\
\hline Day 2 & 23.9 & 76.5 & 43.07 & 13.15 \\
\hline Day 3 & 17.0 & 92.9 & 44.42 & 16.86 \\
\hline Average & 20.9 & 92.5 & 45.42 & 16.31 \\
\hline \multicolumn{5}{|l|}{ Fat } \\
\hline Day 1 & 19.5 & 150.6 & 58.07 & 28.68 \\
\hline Day 2 & 10.1 & 134.2 & 49.21 & 23.14 \\
\hline Day 3 & 7.3 & 93.2 & 52.06 & 21.63 \\
\hline Average & 12.3 & 126 & 53.11 & 24.48 \\
\hline \multicolumn{5}{|l|}{ Vitamin D } \\
\hline Day 1 & 0.0 & 9.6 & 1.52 & 2.48 \\
\hline Day 2 & 0.0 & 18.0 & 2.49 & 3.99 \\
\hline Day 3 & 0.0 & 15.0 & 2.15 & 3.43 \\
\hline Average & 0.0 & 14.2 & 2.05 & 3.30 \\
\hline
\end{tabular}

Table 5 Fulfillment of Patient Diet TB $(\mathrm{N}=36)$

\begin{tabular}{lccccccc}
\hline & \multicolumn{7}{c}{ Consumption criteria } \\
\cline { 2 - 8 } & \multicolumn{2}{c}{ Less } & Adequate & \multicolumn{2}{c}{ Over } \\
\cline { 2 - 8 } & $\mathbf{f}$ & $\mathbf{0}$ & $\mathbf{f}$ & $\mathbf{\%}$ & $\mathbf{f}$ & \% \\
\hline Calory & 31 & 86.1 & 0 & 0 & 5 & 13.9 \\
Carbohydrate & 1 & 2.8 & 29 & 80.6 & 6 & 16.7 \\
Protein & 30 & 83.3 & 0 & 0 & 6 & 16.7 \\
\hline
\end{tabular}


Desy Indra Yani : Diet in The Intensive Phase of Pulmonary Tuberculosis Patients

\begin{tabular}{lcccccc}
\hline Fat & 9 & 25 & 20 & 55.6 & 7 & 19.4 \\
\hline Vitamin D & 36 & 100 & 0 & 0 & 0 & 0 \\
\hline
\end{tabular}

Table 6 Differences in Caloric Needs and Calorie Fulfillment $(\mathrm{N}=36)$

\begin{tabular}{lcc}
\hline & Mean & Std. deviation \\
\hline Average of Calory needed & $2,101.97$ & 413.01 \\
\hline Average of Calory intake & $1,582.30$ & 420.69 \\
\hline Caloric needs and calorie fulfillment & 519.70 & 559.75 \\
\hline
\end{tabular}

respondent's characteristic.

The health characteristics of this study include smoking, nausea, vomiting, smear status, comorbidities, family TB and longterm symptoms.

The majority of respondents were nonsmokers, most respondents also experienced nausea during treatment, positive and negative BTA status was only two people, most respondents did not have any other comorbid illness other than TB, most did not have family members with $\mathrm{TB}$ and most respondents went to Health care provider after symptoms appear less than 4 weeks.

Caloric requirements are known from ideal body weight, and ideal body weight is known by calculating BMI. IMT value obtained by calculating body weight and height of respondents. The nutritional needs of respondents vary so that the researchers present the minimum and minimum value tables, mean and standard deviations of each characteristic.

Table 3 shows that the average caloric needs to be consumed by TB patients was $2,101.97 \mathrm{kcal}$ in one day, when looking at TB nutrition guidelines issued by WHO then $45-65 \%$ of the amount should come from carbohydrates was $945.88-1,366.28$ or if it is converted that was $270.2-390.3$ gr. Then the amount of fat from the total requirement was $25-35 \%(525.49-735.68) \mathrm{kcal}$ or if converted into gram become 58.3-81.7 gr and protein ranged between $15-30 \%$ or $315.2-630.5 \mathrm{kcal}$ or about $78.8-157.6 \mathrm{gr}$.

Diet on the respondents is known from the average intake of nutrients consumed in three days. Dietary components studied in this study included the calories measured in kilocalories, carbohydrates, proteins, fats measured in grams and vitamin D as measured in micrograms. Table 4 presents minimum and maximum values, and mean and standard deviation of each variable.

The consumption and dietary needs of each respondent were adequate. Calorie needs per day of each respondent have been known from the ideal weight of each respondent. The requirement of carbohydrate, protein, and fat per day is $45-65 \% ; 15-30 \% ; 25-$ $35 \%$ of the total calories consumed by each respondent. The need for vitamin D per day is 600 micrograms. Adequacy of the diet is divided into three namely less, enough and more.

Table 6 presents that the fulfillment of diet of TB patients in Garuda and Sukajadi public health centers in Bandung still need additional calories approximately 519.70 $\mathrm{kcal}$, or if converted to carbohydrate aroun $138.5 \mathrm{gr}$, or into protein around $130 \mathrm{gr}$ and if into fat around $58 \mathrm{gr}$.

\section{Discussion}

The respondents' calories consumption need per day should estimate based on the ideal weight of respondent that count using respondents' IMT. The calories counting result is the parameter to decide whether respondents meet their calories need or no. Respondents in category lack of calories when their calories less than the parameter, and meet the calorie need when it above to the parameter.

The study found that the majority respondent $31(86.1 \%)$ had a lack of calories consumed, and only $5(13.9 \%)$ of them consumed calories more than their body need. It was difficult to consume the number of calories exactly as respondent's needs, the parameter used only for a recommendation for their minimal consumption of calories. A previous study that conducted by Wisnugroho 
Desy Indra Yani : Diet in The Intensive Phase of Pulmonary Tuberculosis Patients

(2014) in Surakarta found similar issues which are the majority patient with Tuberculosis (TB) had lack of calories consumed. It is not recommended for TB patient if they lack calories, the patient should have enough calorie consumption or the consumption is more than their body need.

According to WHO standard (2013), the percentage of carbo that should consume by patient TB is $45 \%-65 \%$ of calorie. The patient has met their need when the carbo consumption is $45 \%-65 \%$ per day, and less than $45 \%$ means unmet the calorie need, ad more than $65 \%$ means above their need.

The study found only $1(2.8 \%)$ of respondents had carbo intake less than WHO recommendation, while the majority $29(80.6 \%)$ of respondents had carbo intake as WHO recommendation, and $6(16.7 \%)$ had consumed carbo more than WHO recommendation. Rice was the carbo sources that consumed by the majority of respondents, this may influence by respondents' tribes which are Sundanese, Javanese, and Chinese. Rice is suitable to attain their daily carbo needs. According to WHO recommendation in 2013, patient TB is recommended to have protein daily intake approximately 15-30\% from calorie consumption. The protein need of patients with TB is greater than a healthy person because they need protein for body cells recovery.

This study found that the majority of respondents had protein intake less than WHO recommendation $83.3 \%(n=30)$, and only $16.7 \%(n=6)$ had protein intake as WHO recommendation. This study finding inline with Wisnugroho's study in Surakarta in 2014. He found that a half of patients TB had a lack of daily protein intake. It may because of respondents had limited variety of food and also is influenced by the economic factor.

Respondents' protein sources were nuts products, for example, tofu and tempeh. Some of them also consumed egg, fish, and milk. Only small number of respondents consumed fish as their daily menu, consuming fish was not common for respondents. Although tofu and tempeh is common food for TB patients, they only ate small number and did not eat every day. In fact, the tofu and tempeh are food with high protein, consuming an extra portion of tofu and tempeh could cover the calorie need from protein sources.

Similar to protein, the fat requirement in TB patients is also higher than healthy people (WHO, 2013). Fat is needed by TB patients because in $1 \mathrm{gr}$ of fat there is $9 \mathrm{kcal}$, this is very useful for them to meet their daily calorie needs from fat sources. Percentage of fat requirement from total calorie needs per day is $25-35 \%$. The small percentage of respondents $25 \%(n=9)$ consumed less fat than WHO recommendation, the majority of respondents $55 \%(n=20)$ had an adequate fat intake as a recommendation and few of respondents $7(19.4 \%)$ consumed fat more than the WHO recommendation.

This study found that respondents' fat sources were oils, eggs, milk and dairy products, and fish. Not all respondents consumed milk and dairy products, and only small number of them who ate fish. The oils that also respondents' fat sources were coconut oil used for cooking or coconut oil flavored in instant noodles. Although respondents had different sources of fat, it was not a problem for them because their fat intake was sufficient with their needs.

The need for daily vitamin $\mathrm{D}$ of TB patients also differs from healthy people. According to $\mathrm{AKG}$, the need for vitamin D of people who do not have TB approximately 15 micrograms, while TB patients approximately 600 micrograms. The vitamin $\mathrm{D}$ sources include food intake and the exposure to sunlight. There is no specific recommendation of food as vitamin $\mathrm{D}$ sources. This study found that $100 \%(n=36)$ of respondents consumed vitamin $\mathrm{D}$ less than the $A K G$ recommendation or the standard of TB patients needs. Respondents' food sources of vitamin D mostly salty fish, and milk.

\section{Conclusion}

Diet in patients with pulmonary TB is focused on the fulfillment of calories per day based on patients' ideal weight. The patients' calories sources were macronutrients including carbohydrates, proteins, and fats. Fulfillment of TB patients' calories is needed to deal with increasing body's metabolic processes because of TB. The majority of TB patients 
Desy Indra Yani : Diet in The Intensive Phase of Pulmonary Tuberculosis Patients

who participated in this study had not enough intake of calories as recommended by several sources. However, they consumed sufficient carbohydrates. The majority of respondents had protein intake less than their needs, the similar trend also happened related to fats intake and vitamin $\mathrm{D}$ daily consumption.

The study showed that the majority of TB patients who participated in this study were not fulfilled their daily intake of calories, protein, and vitamin $\mathrm{D}$. The researchers recommend the PHC especially out-patients services of TB or DOTS to have collaboration with nutritional services to develop collaborative interventions including providing nutrition counseling or supplementary food for patients with TB. The TB patients should have nutrition counseling as well as health education related to TB transmission. The contents of counseling would be better if it focused on reminding TB patients about consuming various food that would impact to fulfillment protein need as they did to fulfill their carbohydrates and fats need. According to the study findings, there is a need for future study especially in assessing factors that influence to a diet of pulmonary TB patients in the intensive phase and also a qualitative study that would explore in depth related to the diet of TB patients in the intensive phase in the areas of Bandung city.

\section{References}

Beck, M.E. (2011). Ilmu gizi dan diet: Hubungannya dengan penyakit-penyakit untuk perawat dan dokter. Yogyakarta: Yayasan Essentia Medica.

Birlie A., Tesfaw G., Dejene T., \& Woldemichael K. (2015). Time to death and associated factors among tuberculosis patients in Dangila Woreda, Northwest Ethiopia. PLoS ONE, 10(12), e0144244. doi:10.1371/journal.pone.0144244.

Dodor E. (2008). Evaluation of nutritional status of new tuberculosis patients at the effia-nkwanta regional hospital. Ghana Med. J., 42(1), 22-8. (http://www.ncbi.nlm.nih. gov/pmc/articles/PMC2423338/).
Hanrahan, C.F. et al. (2010) Body mass index and risk of tuberculosis and death. AIDS, 24(10), 1501-8. doi: 10.1097/ QAD.0b013e32833a2a4a.

Henning, M. (2009). Nursing's role in nutrition. Comput Inform Nurs, 27(5), 3016. doi: 10.1097/NCN.0b013e31819f7ca8. PubMed PMID: 19726924.

Khan A., Sterling T.R., Reves R., Vernon A., \& Horsburgh, C.R. (2006). Lack of weight gain and relapse risk in a large tuberculosis treatment trial. Am. J. Respir. Crit. Care Med., 174(3), 344-8. doi: 10.1164/rccm.200511$18340 \mathrm{OC}$.

Krapp, F., Veliz, J.C., Cornejo, E., Gotuzzo, E., \& Seas, C. (2008). Bodyweight gain to predict treatment outcome in patients with pulmonary tuberculosis in Peru. Int. $J$. Tuberc. Lung Dis., 12(10),1153-9.

Lai, H-H., Lai, Y-J., \& Yen Y-F. (2017) Association of body mass index with timing of death during tuberculosis treatment. PLoS ONE, 12(1), e0170104.

Lonnroth K., Williams, B.G., Cegielski, P., \& Dye, C. (2010). A consistent log-linear relationship between tuberculosis incidence and body mass index. Int J Epidemiol 39(1), 149-155.

Mack, U., Migliori, G.B., Sester, M., Rieder, H.L., Ehlers, S., Goletti, D., et al. (2009). LTBI: Latent Tuberculosis Infection or lasting immune responses to M. tuberculosis? A TBNET consensus statement. Eur Respir J 33(5), 956-973.

Metcalfe, N. (2005). A study of tuberculosis, malnutrition and gender in Sri Lanka. Trans. R. Soc. Trop. Med. Hyg., 99(2), 115-9.

Nnoaham, K.E., \& Clarke, A. (2008). Low serum Vitamin D levels and tuberculosis: A systematic review and meta-analysis. Int $J$ Epidemiol, 37(1), 113-119.

Podewils, L.J., Holtz, T., Riekstina, V., Skripconoka, V., Zarovska, E., Kirvelaite, G., et al. (2011). Impact of malnutrition on 
Desy Indra Yani : Diet in The Intensive Phase of Pulmonary Tuberculosis Patients

clinical presentation, clinical course, and mortality in MDR-TB patients. Epidemiol Infect, 139(1), 113-120.

Polit, D., \& Beck, C.T. (2014). Essentials of nursing research: Appraising evidence for nursing practice ( $8^{\text {th }}$ Ed.). Philadelphia: Wolters Kluwer Health.

PrayGod, G., Range, N., Faurholt-Jepsen, D., Jeremiah, K., Faurholt-Jepsen, M., Aabye, M.G., et al. (2011). Weight, body composition and handgrip strength among pulmonary tuberculosis patients: A matched cross-sectional study in Mwanza, Tanzania. Trans R Soc Trop Med Hyg, 105(3), 140-147.

Schaible, U.E., \& Kaufmann, S.H. (2007). Malnutrition and infection: Complex mechanisms and global impacts. PLoS Med, $4(5)$, e115.

Thompson, F.E., \& Subar, A. (2008). Dietary assessment methodology; in Coulston A, Boushey C (eds): Nutrition in the Prevention and Treatment of Disease ( $\left.2^{\text {nd }} E d.\right)$. Amsterdam: Elsevier.

Waitt, C.J., \& Squire, S.B. (2011). A systematic review of risk factors for death in adults during and after tuberculosis treatment. Int J Tuberc Lung Dis, 15(7), 871-885.

Webster-Gandy, J., Madden, A., \& Holdsworth, M. (2014). Gizi dan dietetika. Jakarta: EGC.

Wisnugroho, Y. (2014). Hubungan asupan makronutrien dan mikronutrien dengan status gizi pada penderita TB paru di BBKPM Surakarta.

World Health Organization. (1999). Management of severe malnutrition: a manual for physicians and other senior health workers. Geneva (http:// www.who.int/nutrition/publications/ severemalnutrition/9241545119/en).

World Health Organization. (2013). Guidelines: Nutritional care and support for patients with tuberculosis. Geneva.

Zachariah, R., Spielmann, M.P., Harries, A.D., \& Salaniponi, F.M. (2002). Moderate to severe malnutrition in patients with tuberculosis is a risk factor associated with early death. Trans $R$ Soc Trop Med Hyg, 96(3), 291-294. 